\title{
The Gydratny Fault zone of Lake Baikal
}

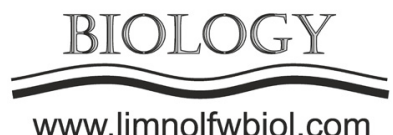

www.limnolfwbiol.com

\author{
Solovyeva M.A. ${ }^{1 *}$, Akhmanov G.G. ${ }^{1}$, Mazzini A. ${ }^{2}$, Khabuev A.V. ${ }^{3}$, Khlystov O.M. ${ }^{3}$ \\ ${ }^{1}$ Lomonosov Moscow State University, Leninskie Gory Str., 1, Moscow, 119991, Russia \\ ${ }^{2}$ Centre for Earth Evolution and Dynamics (CEED) University of Oslo, ZEB-bygningen Sem Saelandsvei 2A, Blindern, 0371 Oslo, Norway \\ ${ }^{3}$ Limnological Institute, Siberian Branch of the Russian Academy of Sciences, Ulan-Batorskaya Str., 3, Irkutsk, 664033, Russia
}

\begin{abstract}
The Central basin of Lake Baikal is intersected by the North-East - South-West-oriented escarpment named the «Gydratny Fault zone». This laterally extensive structure runs subparallel to the North-Western shore of the lake. The Gydratny Fault zone has been investigated using geophysical techniques during 6 years of research in the framework of international expeditions of the Class@Baikal project. The acquired seismic data provided details of the structure of the upper part of the sedimentary section revealing a system of previously unknown faults. A new tectonic scheme of the South-Western deep-water part of the Central basin is presented. The Gydratny fault is accompanied by a system of numerous synthetic and antithetic normal faults that form a wide and extended faulted zone. These structures are unevenly distributed, and include modern and active faults as well as features buried under undeformed sedimentary units with different thickness. This parameter is used to constrain the patterns observed in several zones of the study area. The difference in the characteristics of faults and their manifestations on seismic data can be explained by complex and uneven distribution of active tectonic and sedimentary processes.
\end{abstract}

Keywords: Lake Baikal, Baikal rift zone, seismic survey, neotectonic

\section{Introduction}

Lake Baikal is located in the Central segment of the Baikal rift system. It is a zone of junction of the East Siberian platform and the Sayan-Baikal mobile belt. The Baikal basin is the oldest and largest element of the rift system. The age of the basin has been broadly debated and suggested to be 25-30 Ma (Hutchinson et al., 1993; Zonenshain et al., 1995; etc.) or 60-70 Ma (Logachev, 1974; 2003; Nikolaev, 1998; Mats et al., 2001; etc.). The long development of the Baikal rift involved the change of sources and stress vectors (Mats, 2015) leading to a complex system of tectonic faults.

The tectonic studies of South Eastern Siberia and adjacent territories date back to the 60 s and numerous alternative maps have been proposed (Solonenko, 1965; Sherman, 1977; Levi, 1997; 2002; etc.). The first tectonic schemes of the Baikal subsurface were proposed after structural-geological and seismic studies completed during 1989-1994 (Levi, 1995). Later, they were reviewed and updated, based on the same geophysical data and using additional seismic data (Levi, 1997; Seminskiy et al., 2001; Logachev, 2003; Lukhnev et al., 2013; Lunina et al., 2014; Lunina, 2016) (Fig. 1).
The results of international expeditions of the Class@Baikal project in 2014-2019 allowed to advance in the detailed mapping of tectonic faults.

Between 2014-2019, the Class@Baikal international program acquired $\sim 2000 \mathrm{~km}$ of seismic profiles from the Central basin of the Lake Baikal (Akhmanov, 2018). This major achievement doubles the data volume of all previous surveys (Fig. 2b) and allowed to detect and map a large system of modern faults in the South-Western part of the Central Baikal basin. Our new data led to a review and significant improvement of existing schemes of tectonic features.

\section{Morphology of the bottom relief}

The research area occupies the South-Western deep-water part of the Central Baikal basin (Fig. 2a). The bathymetric map of the area shows a large escarpment in the bottom relief: This feature extends from Cape Uhan on the Olkhon Island towards the South-West for almost $30 \mathrm{~km}$ (Fig. 2b, Fig. 2d). Its height gradually decreases towards the South-West declining from 100 to 0 meters. The structure was described by Kuz'min in 2004 based on echo sounder measurements, although

*Corresponding author.

E-mail address: marina-sol@yandex.ru (M.A. Solovyeva) 

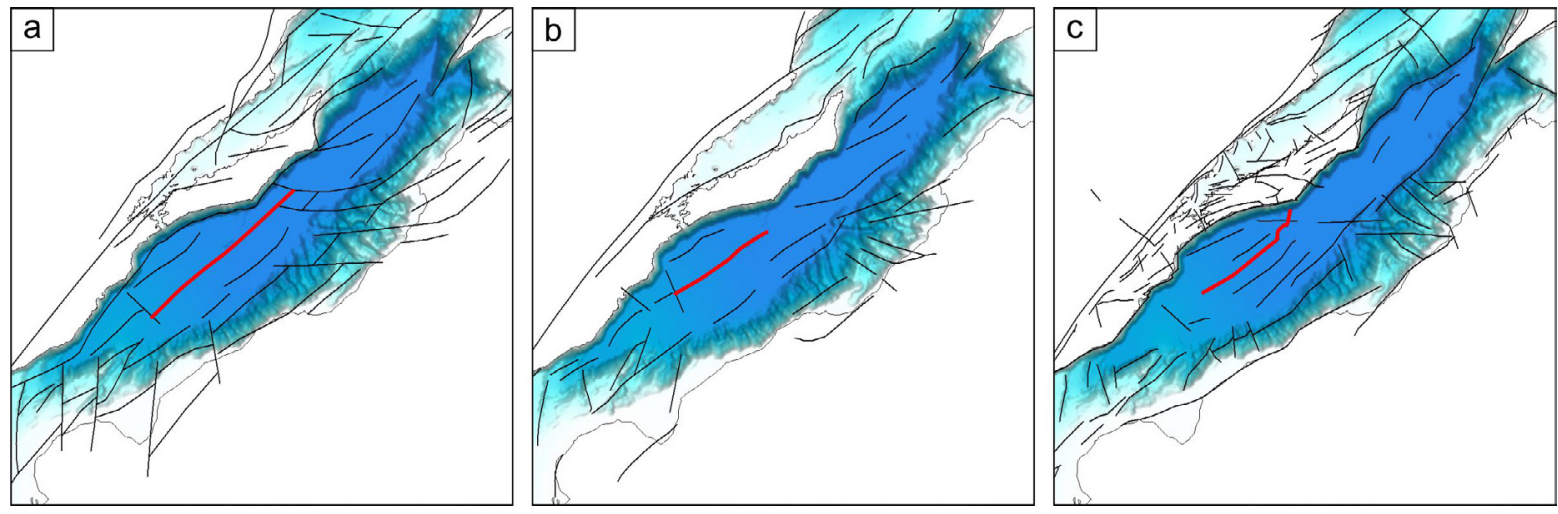

Fig. 1. Tectonic schemes of the Central Baikal basin: (a) by (Levi, 1997); (b) by (Logachev, 2003); (c) by (Lunina, 2016)

its geometry and characteristics were obtained in 2002 during a side-scan sonar and a multibeam echo sounder survey completed in the framework of the INTAS international project (De Batist et al., 2002). In 2009 , multibeam bathymetric studies were conducted in the framework of the LIN SB RAS (Russia) and RCMG (Belgium) international project (Bathymetry data..., 2009). These data allowed improving the detail of the digital model of the bottom relief and more accurately to determine the position and the morphology of the scarp.

Numerous structures of focused hydrocarbon gas discharge and near-surface gas hydrates accumulations are associated with this tectonic scarp. For this reason in 2018 was proposed to name this structure Gydratny fault, i.e. Gydratny as «gas hydrates bearing» (Khlystov, 2018).

The bottom relief defining the Gydratny fault is irregular and is represented by curved segments that bend towards the North-West. The North-Western raised block (block 1) is characterized by an uneven distribution of slope directions. Its South-Eastern flank is raised relative to the Central part of this block (Fig. 2c). Therefore the azimuths of the slope directions take a predominantly Northern and North-Western direction. This block is adjacent to the Olkhon and Near-Olkhon tectonic blocks, which are sitting at lower bathymetry relative to the uplifted Primorsky Ridge along listric normal faults (Levi, 1995). Their SouthEastern block flanks are also being elevated relative to the North-Western ones (Fig. 2c). Listric faults are quite typical for the tectonic structure of the Olkhon Island and its adjacent areas (Levi, 1995). In agreement with the general tectonic setting and the similarity with the neighbouring tectonic blocks and faults, the Gydratny fault can also be considered as a listric normal fault. The lowered block is characterized by the presence of secondary multiple small faults on the hanging wall (synthetic and antithetic), which were mapped during Class@Baikal expeditions (Fig. 3a, Fig. 3c).

\section{Material and methods}

The existing database of geophysical data collected during 1992-2002 was complemented with new seismic profiles collected during the 2014-2019 Class@Baikal expeditions (Fig. 2b).These geophysical surveys were carried out using the method of continuous seismic-acoustic profiling using an electric spark source («sparker») with a central frequency of $300 \mathrm{~Hz}$ and a chirp profiler with linear modulation of frequencies from 1 to $10 \mathrm{kHz}$. This methodology of two-frequency surveys allowed us to study near-surface deposits (upper 30 meters) with a high resolution and also to obtain data of the sedimentary section to a depth of about $300 \mathrm{~m}$ below the lake floor.

The analysis of the wave pattern on the seismic sections allowed to investigate sediment structures and to trace faults locations. Faults were detected by characteristic kinematic and dynamic features, such as: discontinuity and displacement of the reflectors, a sharp lateral change in the wave pattern, the formation of diffracted waves, and a decrease in the amplitude and frequency of the reflected signal.

Each one of the identified faults was scrutinized for the following criteria: a) the location of the hanging wall and footwall relative to fault, b) the vertical amplitude of the sediment displacement and c) the depth at which the displacement is observed (i.e. the thickness of undisturbed sediments covering each fault) (Fig. 3). Neighbouring faults with similar characteristics were traced in the seismic profiles. This approach allowed to compile a detailed scheme of tectonic faults in the upper part of the sediment section.

\section{Results and discussion}

The newly detected and mapped tectonic faults are interpreted as branching off from the main Gydratny fault. The map catalogue is summarized in Fig. 4. The study area can be divided in two main blocks (hanging wall and footwall, separated by the Gydratny fault), which can be partitioned into 6 zones with fundamentally different geological structure.

The first block (footwall, block 1) is bounded on the North-West by the Obruchev (Olkhon) fault and on the South-East by the Gydratny fault (Fig. 2c). It is a large tectonic block, is essentially undisturbed by tectonic faults and is raised relative to the block 2. Block 1 can be divided into two zones. The whole NorthEast part (zone 1A) is a tectonically undisturbed block where no faults can be observed in the upper $300 \mathrm{~m}$ of sediments. Bordering this zone, the portion of Gydratny fault forms a well-expressed scarp in bottom relief. This 


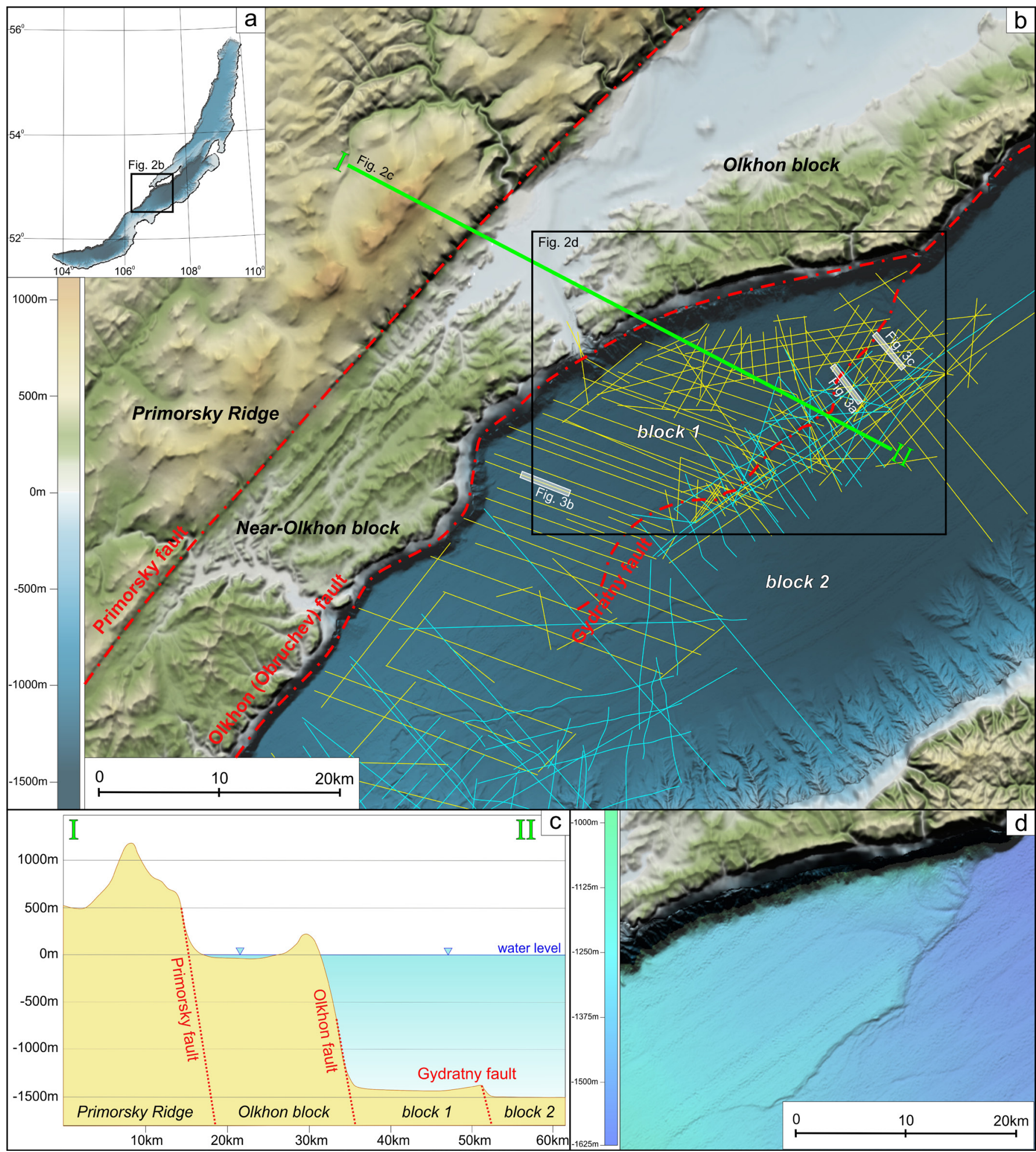

Fig. 2. Overview scheme of the relief in the study area near the Gydratny fault. (a) Lake Baikal with the location of the research area (black polygon); (b) A scheme of seismic data obtained in the Class@Baikal project expeditions in 2014-2019 (yellow lines) and previous surveys in 1992-2002 (blue lines). White frames show the location of fragments of seismic profiles shown in Fig. 3. Green line shows the location of the profile I-II of the bottom relief schematized in panel c. The black polygon frames the area with detailed bathymetry (panel d), where the Gydratny fault is well expressed in the bottom relief. Bathymetry data: LIN SB RAS and RCMG-RAS Program 17.8 (2009) and FWO Flanders Project (1.5.198.09). 


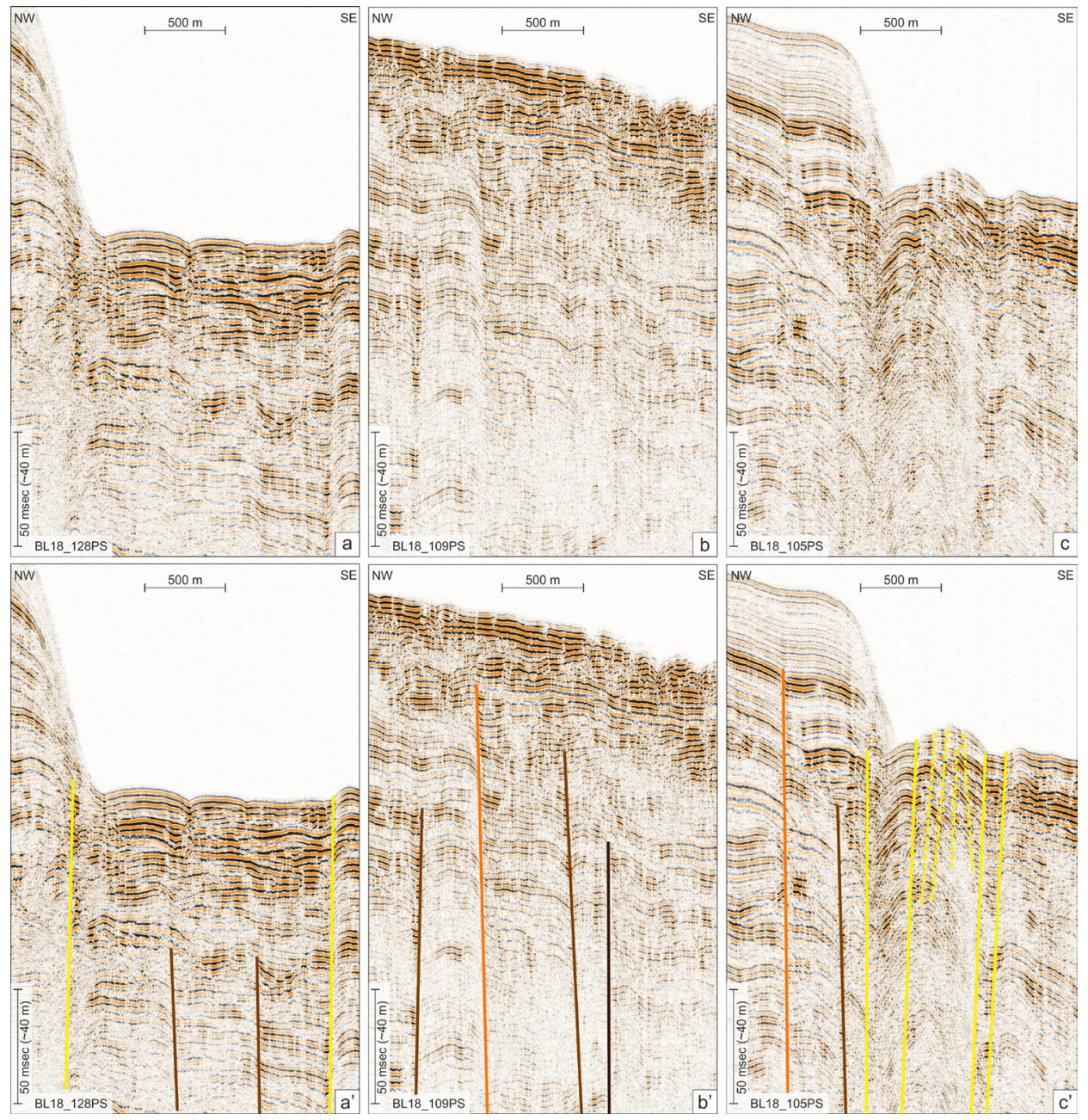

Fig. 3. Examples of identifying tectonic faults on seismic data with fault typization based on the thickness of overlapping sediments. Upper row: seismic sections without interpretation; the lower row: seismic sections with elements of interpretation. Yellow lines show faults that reach to the lake floor (type $\alpha$ ), while the other coloured lines indicate faults covered by sediments with a thickness of about 10-40 m (orange lines, type $\beta$ ), 40-85 m (light brown lines, type $\gamma$ ), over $85 \mathrm{~m}$ (dark brown lines, type $\delta$ ). The location of the profiles fragments is shown in Fig. $2 \mathrm{~b}$.

zone is characterized by North-West azimuth of the slope directions.

The neighbouring zone of the first tectonic block (zone $1 B$ ) is located in the South-Western part of the study area and is also bounded by the Olkhon and Gydratny faults. A system of five deep faults covered by thick layers of sediments (up to $150 \mathrm{~m}$ ) can be traced here. These form a graben-like structure elongated in North-East direction. The amplitude of the sediment displacement reached up to 40 meters.

The second block (hang wall, block 2) occupies a broad area in the deep-water part of the lake. It adjoins to the Gydratny fault at the North-West and bounded on the South-East by the foot of the slope of the Central Baikal basin. This area is characterized by extensive faulting. These faults are mostly parallel to the Gydratny fault and accordingly also extend from the South-West to the North-East forming a single wide fault zone (zones $2 A, 2 B$ and $2 C$ ) that extended for 65 $\mathrm{km}$. This heavily faulted region extends from the foot of the Kukuy canyon on the avandelta of the Selenga River to Cape Ukhan on Olkhon Island. We named this zone the Gydratny Fault zone and its width varies from 5 to $11 \mathrm{~km}$. The faults inside this zone form a series of synthetic and antithetic discharges with the lowered South-East and North-West wing respectively. They form several local small grabens in the Central part of this fault zone. All faults are sub-vertical in the upper part of the sediment section and characterized by a distinctly expressed vertical component of movement. Due to the low penetration of the acoustic dataset, the faults roots are not imaged. The amplitude of sediments displacements increases with depth. Most faults are characterized by small amplitudes of sediments displacements in the upper part of the section and they are often replaced by flexures with deformation of layers without their rupture. This may indicate a high plasticity of the sediment or slow displacements along the faults.

All the detected faults are characterized by different location depth on the fault plane. Some structures reached the lake floor, while others are covered by undeformed sediments with different thickness. Using this parameter, all faults were divided into modern active faults (reaching the bottom surface, type $\alpha$ ) and 3 groups of faults covered by sediments with a thickness of 10-40 m (up to 50 msec below the lake floor level on seismic sections, type $\beta$ ), 40-85 m 


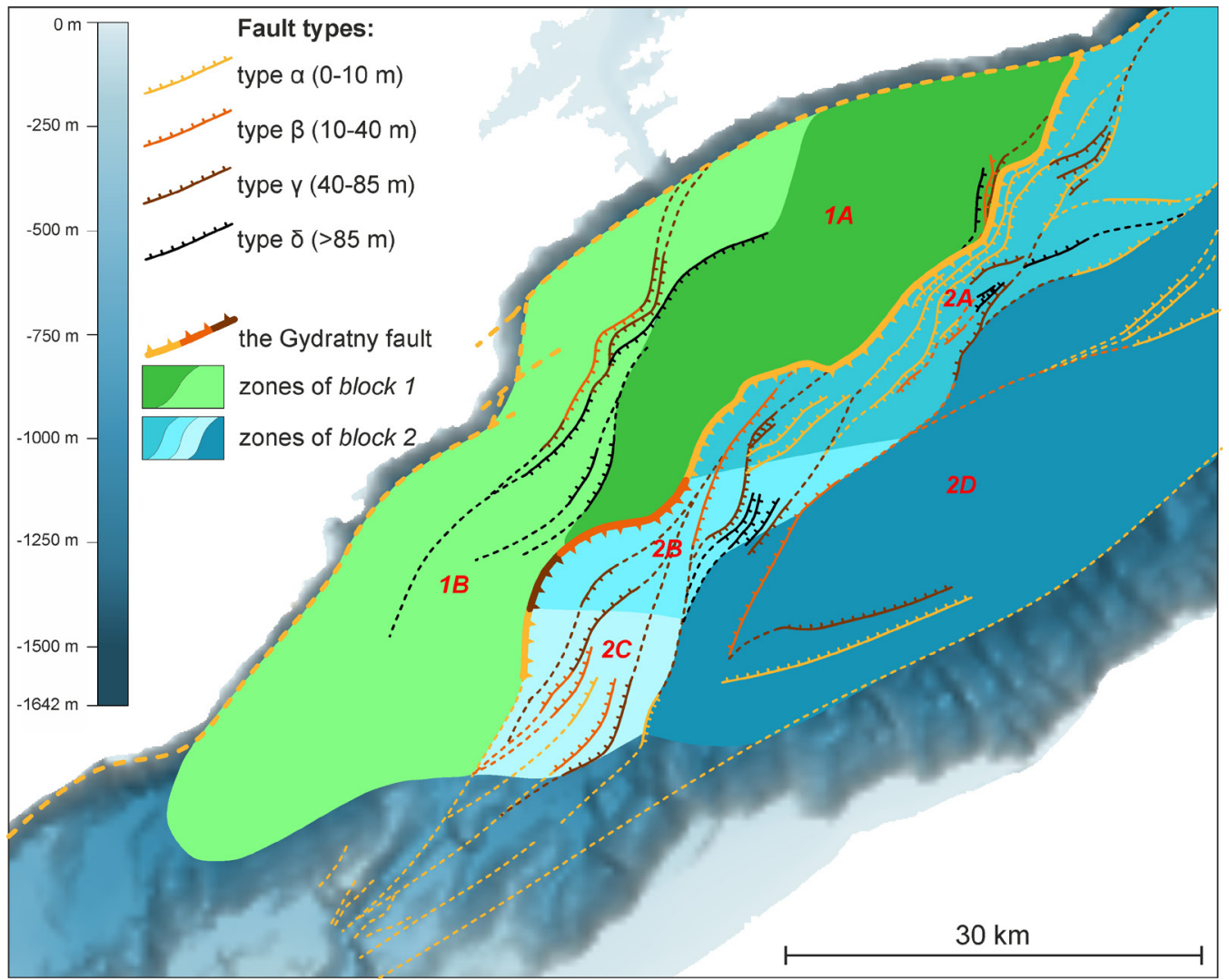

Fig. 4. The scheme of tectonic Gydratny Fault zone with classifying based on the thickness of overlapping sediments. Solid lines show proved established faults, dotted lines show assumed faults. The names of the zones are indicated in red font.

(50-100 msec, type $\gamma$ ) and over $85 \mathrm{~m}$ (more than 100 msec, type $\delta$ ). Moreover, the most laterally extensive faults can reach the lake floor in one portion, and be buried under the modern sediments in the other one.

The different types of faults appear to be distributed irregularly (Fig. 4). In the North-Eastern segment of the Gydratny Fault zone (zone $2 A$ ), most of the faults reach the lake floor (type $\alpha$ ). In the Central segment (zone $2 B$ ), almost all faults are buried under a thick layers of sediments (mostly types $\gamma$ and $\delta$ ). Ultimately the South-Western segment (zone 2C) is characterized by a complex combination of faults of different types ( $\alpha, \beta$, and $\gamma)$.

This complex pattern can be explained by the multidirectional action of tectonic and lithodynamic processes. This would imply that in the Central and South-West segments (zones $2 B$ and $2 C$ ) of the Gydratny Fault zone there is a slower displacement along the faults or/and that here are present higher sedimentation rates. Hence in this area can be deposited undisturbed layers of sediments. This scenario is consistent with the observed intensive accumulation of terrigenous material supplied through the Kukuy canyon by the Selenga River (Solovyeva, 2018). Also, slow displacements along the faults are confirmed by presence of flexures above some of faults. The North-Eastern part of the fault zone (zone $2 A$ ) is characterized by low sedimentation rates due to the large distance from major suppliers of terrigenous material. This probably explains the presence of faults in this area that reach the lake floor.

The Eastern part of block 2 (zone 2D) is characterized by a small spread of faults in the upper part of the sedimentary section. All of the tectonic structures extend sub-parallel to the axis of the Baikal basin and are normal faults with a North-Western lowered wing. The largest amount of modern active faults is also found in the North-Eastern part of this zone.

\section{Conclusions}

Extensive geophysical investigations conducted in the framework of the Class@Baikal project, allowed us to build a new tectonic scheme for a portion of the Central basin of the Lake Baikal. These newly acquired significantly improve our knowledge of the tectonic setting of this part of the lake revealing a broad and complex system of synthetic and antithetic faults distributed sub parallel to the Gydratny fault. We name this extensively faulted region the Gydratny Fault zone. A detailed classification of the identified faults reveals a complex and uneven distribution of modern active and older buried faults. This pattern is ascribed to the uneven tectonic activity and to the differing sedimentary processes ongoing at the various segments of the Gydratny Fault zone.

\section{Acknowledgements}

This study was carried out with the financial support of the RFBR in the framework of project No. 18-35-00363. 
We acknowledge the support of the Research Council of Norway (NFR) through the HOTMUD project number 288299 and its Centers of Excellence funding scheme, project number 223272 (CEED).

\section{References}

Akhmanov G.G. 2018. The newly discovered «MSU» gas-hydrate bearing seep and other findings: five years of the Class@Baikal Project. In: VII International Conference on Marine Research and Education, Vol. II, pp. 51-55.

Bathymetry data of LIN SB RAS and RCMG after RAS 17.8 Program (2009) and FWO Flanders (1.5.198.09) Project. 2009. [URL: http://lin.irk.ru/multibeam/ru/results Access date 10.02.2020]

De Batist M., Canals M., Sherstyankin P. et al. \& the INTAS Project 99-1669 Team. 2002. A new bathymetric map of Lake Baikal. [URL: http://www.lin.irk.ru/intas/index.htm Access date 10.02.2020]

Hutchinson D.R., Gol'mshtok A.Yu., Zonenshain L.P. et al. 1993. Preliminary results from 1989 multichannel seismic reflection survey in Lake Baikal. Geologiya i Geofizika [Russian Geology and Geophysics] 34: 25-36. (in Russian)

Khlystov O.M. 2018. Gas hydrate bearing capacity and tectonics of Central Baikal. In: VII International Conference on Marine Research and Education, Vol. II, pp. 43-44.

Kuz'min M.I., Lut B.F., Sherstyankin P.P. 2004. Obruchev fault in the Baikal basin as the object of researches of Earth sciences. Geografiya i Prirodnye Resursy [Geography and Natural Resources] 2: 35-40. (in Russian)

Levi K., Babushkin S., Badardinov A. et al. 1995. Active Baikal tectonics. Russian Geology and Geophysics 36: 143-154.

Levi K.G., Miroshnichenko A.I., San'kov V.A. et al. 1997. Active faults of the Baikal depression. Bulletin du Centre de Recherches Elf Exploration Production [Elf Exploration Production Research Center Bulletin] 21: 399-434.

Levi K.G., Yazev S.A., Zadonina N.V. 2002. Sovremennaya geodinamika i geliogeodinamika [Modern geodynamics and heliogeodynamics]. Irkutsk: Irkutsk State Technical University Publishing House.(in Russian)

Logachev N.A. 1974. Sayano-Baykal'skoye Stanovoye nagor'ye [Sayan-Baikal Stanovoi uplift]. In: N.A. Florensov (Ed.), Nagor'ya Pribaykal'ya i Zabaykal'ya [Uplifts of pre-Baikalian and transbaikalian regions]. Moscow, pp. 16-162. (in Russian)

Logachev N.A. 2003. History and geodynamics of the Baikal rift. Geologiya i geofizika [Russian Geology and
Geophysics] 44: 391-406. (in Russian)

Lukhnev A.V., San'kov V.A., Miroshnichenko A.I. et al. 2013. GPS-measurements of recent crustal deformations in the junction zone of the rift segments in the central Baikal rift system. Russian Geology and Geophysics 54: 1417-1426. DOI: 10.1016/j.rgg.2013.10.010

Lunina O.V., Caputo R., Gladkov A. et al. 2014. Southern East Siberia Pliocene-Quaternary faults: database, analysis and inference. Geoscience Frontiers 5: 605-619. DOI: 10.1016/j.gsf.2013.12.006

Lunina O.V. 2016. The digital map of the PlioceneQuaternary crustal faults in the Southern East Siberia and the adjacent Northern Mongolia. Geodynamics \& Tectonophysics 7: 407-434. DOI: 10.5800/GT-2016-7-3-0215

Mats V.D., Ufimtsev G.F., Mandel'baum M.M. et al. 2001. Kaynozoy Baykal'skoy riftovoy vpadiny: stroyeniye i geologicheskaya istoriya [The Baikal basin in the Cenozoic: structure and geologic history]. Novosibirsk: Siberian Branch of RAS Publishing House, Filial "Geo". (in Russian)

Mats V.D. 2015. The Baikal rift: Pliocene (Miocene) - Quaternary episode or product of extended development since the Late Cretaceous under various tectonic factors. A review. Geodynamics \& Tectonophysics 6: 467-489. DOI: 10.5800/GT-2015-6-4-0190

Nikolaev V.G. 1998. Age of origin of the Baikal basin. Byulleten' Moskovskogo Obshchestva Ispytateley Prirody. Otdel Geologicheskiy [Bulletin of Moscow Society of Naturalists. Geological section] 73: 13-16. (in Russian)

Seminskiy K.Zh., Karabanov E.B., Kuz'min M.I. 2001. Tectonic disturbances of Lake Baikal sediments (based on the study of core of the BDP-98). Geologiya i Geofizika [Russian Geology and Geophysics] 42: 308-318. (in Russian)

Sherman S.I. Fizicheskiye zakonomernosti razvitiya razlomov zemnoy kory [Physical patterns of crustal fault development]. 1977. Novosibirsk: Nauka. (in Russian)

Solonenko V.P. 1965. Live tectonics in the Pleistocene region of the Muisky earthquake. Izvestiya Akademii nauk SSSR. Seriya geologicheskaya [Bulletin of the Academy of Sciences of the USSR. Geologic series] 4: 58-70. (in Russian)

Solovyeva M.A., Akhmanov G.G., Klystov O.M. et al. 2018. Five years of geological-geophysical studies of the Khuray deep-water depositional system (Lake Baikal). In: VII International Conference on Marine Research and Education, Vol. II, pp. 136-139.

Zonenshain L.P., Kaz'min V.G., Kuz'min M.I. 1995. New data on the Baikal history: observations from manned submersibles. Geotektonika [Geotectonics] 3: 46-58. (in Russian) 